\title{
MAKNA SIMBOLIK RITUAL SELAMATAN METHIK PARI DALAM PANDANGAN AGAMA BUDDHA DI DESA GEMBONGAN KECAMATAN PONGGOK KABUPATEN BLITAR
}

\author{
Sindhu Kusalanana', Metta Puspita Dewi ${ }^{2}$, Marjianto ${ }^{3}$ \\ Kantor Kementerian Agama Kabupaten Sorong ${ }^{1}$ \\ STABN Raden Wijaya ${ }^{23}$ \\ Sindhukusalanana22@gmail.com
}

\begin{abstract}
ABSTRAK
Tujuan penelitian menjelaskan sejarah ritual selamatan methik pari,menjelaskan simbol ritual selamatan methik pari dan mengkaitkan makna simbolik selamatan methik pari dengan pandangan Agama Buddha. Penelitian ini menggunakan metode kualitatif dengan pendekatan studi kasus. Tempat penelitian di Desa Gembongan Kecamatan Ponggok Kabupaten Blitar. Data dikumpulkan melalui observasi, wawancara dan dokumentasi. Keabsahan data menggunakan triangulasi tehnik dan triangulasi sumber. Teknik analisis data mengacu pada konsep Milles \& Huberman dengan pengumpulan data, redusksi data, penyajian data, dan penarikan kesimpulan. Hasil penelitian menjelaskan sejarah ritual selamatan methik pari,menjelaskan makna simbolik ritual selamatan methik pari, dan mengkaitkan makna simbolik ritual selamatan methik pari dengan pandangan Agama Buddha diwujudkan dalam bentuk (1) Pattidana yang digambarkan sesajian cokbakal; (2) Mahabuta 4 dan dana digambarkan dalam sesajian nasitakir; (3) Keharuman kebajikan yang digambarkan dalam bentuk persembahan dupa.
\end{abstract}

\section{Kata kunci : Methik pari, Makna Simbolik, dan Agama Buddha}

\begin{abstract}
The purposes of the study are to explain the history of the methik pari ritual, to explain the symbol of the methik pari ritual and relate the symbolic meaning of the methik pari ritual to the Buddhism views. This study uses qualitative methods with a case study. This research site in Gembongan Village, Ponggok District, Blitar Regency. Data was collected through observation, interviews and documentation. The validity of the data uses technical triangulation and source triangulation. Data analysis refers to the concept of Milles \& Huberman by collecting data, reducing data, presenting data, and drawing conclusions. The results of this study are explain the history of the methik pari ritual, explain the symbolic meaning of the methik pari ritual, and relate the symbolic meaning of the methik pari ritual with the view of Buddhism embodied in the form of (1) Pattidana which is depicted in a cokbakal; (2) Mahabuta 4 and dana are depicted in a nasi takir; (3) The wisdom of fragrance described in the form of incense offerings.
\end{abstract}

Keywords: Methik pari, symbolic meaning, and Buddhist views 


\section{PENDAHULUAN}

Indonesia merupakan salah satu negara yang memiliki keanekaragaman budaya. Setiap daerah mempunyai ciri khas kebudayaan tersendiri yang perlu dilestarikan agar kekayaannya tetap terjaga. Menurut Sujarwo (1998: 10-11), kebudayaan adalah seluruh sistem gagasan tindakan dan hasil karya manusia untuk memenuhi kehidupannya dengan cara belajar, yang semuanya tersusun dalam kehidupan masyarakat. Keberagaman budaya itu dipengaruhi oleh berbagai faktor, seperti letak geografis, pola hidup, pola bercocok tanam, dan berbagai kepercayaan yang dianut oleh daerah setempat. Adanya faktor tersebut akan melahirkan sebuah keberagaman budaya, adat istiadat, bahasa daerah, rumah adat, dan kesenian tradisi. Bahasa dan kebudayaan merupakan dua hal yang saling mempengaruhi. Bahasa selalu menggambarkan masyarakat yang bersangkutan, lebih lagi bahasa di dalam kebudayaan. Setiap daerah mempunyai bahasa dan kebudayaaan yang berbeda-beda. Keanekaragaman budaya terlihat misalnya pada perbedaan mata pencaharian.

Mata pencaharian bercocok tanam dalam sejarah perkembangan kebudayaan manusia muncul setelah adanya kegiatan berburu. Penemuan kepandaian bercocok tanam merupakan suatu peristiwa yang sangat penting dalam proses perkembangan kebudayaan umat manusia. Kepandaian bercocok tanam tersebut terjadi secara berangsur-angsur, upaya tersebut mula-mula diawali dengan mempertahankan tumbuhtumbuhan tertentu terhadap serangan hewan atau terhadap tanaman lain yang dapat merusak.

Salah satu contoh mata percaharian bercocok tanam adalah menanam padi. Penanaman padi diawali dengan pembajakan sawah. Upacara pembajakan sawah telah ada dalam sejarah agama Buddha. Menurut Mingun (2009:521) upacara membajak sawah sudah dilakukan sejak masa kehidupan Pangeran Sidharta dan upacara ini merupakan upacara rutin yang dilakukan setiap tahun di kota Kapilavathu. Dari hal tersebut dapat disadari bahwa awal dari upaya manusia untuk melakukan kegiatan bercocok tanam berkaitan dengan apa yang mereka tanam. Seperti juga dengan kegiatan bercocok tanam di Desa Gembongan yang mayoritas masyarakatnya masih melakukan kegiatan menanam padi di sawah.

Menanam padi di sawah merupakan kebudayaan yang sudah berkembang di masyarakat. Kebudayaan sendiri merupakan karya manusia yang dapat tumbuh dan berkembang sehingga menunjukkan ciri dan karakter sebuah bangsa atau daerah. Kebudayaan adalah seluruh sistem gagasan, tindakan, dan hasil karya manusia dalam rangka melaksanakan kehidupan sosial 
masyarakat yang dijadikan hak milik diri manusia melalui belajar. Dengan demikian hampir seluruh tindakan manusia dapat disebut "kebudayaan", karena jumlah tindakan yang dilakukan dalam kehidupan bermasyarakat yang tidak dibiasakannya dengan belajar. Kebudayaan yang dimiliki setiap bangsa atau masyarakat merupakan suatu sistem yang terdiri atas unsur-unsur suatu kesatuan. Menurut Koentjaraningrat (1990:203-204) menjelaskan bahwa unsurunsur kebudayaan teridiri dari bahasa, sistem pengetahuan, organisasi sosial, sistem peralatan hidup dan teknologi, sistem mata pencaharian, sistem religi dan kesenian.

Salah satu contoh kebudayaan yang ada di Negara Indonesia adalah diadakannya ritual sebelum pelaksanaan methik pari. Ritual merupakan tata cara dalam pelaksanaan upacara atau suatu perbuatan keramat yang dilakukan oleh masyarakat untuk mendapatkan tujuan tertentu. Ritual telah dijadikan sebagai tradisi oleh masyarakat, termasuk oleh komunitas agama yang memiliki berbagai variasi tujuan.

Ritual ditandai dengan adanya berbagai macam unsur dan komponen. Komponen tersebut terdiri atas adanya waktu, tempat dimana upacara dilakukan, alat-alat dalam upacara, serta orang-orang yang menjalankan upacara. Sebelum pelaksanaan methik pari, orang-orang dalam sebuah masyarakat melaksanakan ritual atau upacara agar tujuannya dalam pelaksanaan methik pari berjalan dengan lancar dan mendapat berkah dari Yang Maha Kuasa. Ritual dapat memiliki fungsi sosial yang mengungkapkan, memperbaiki dan memperkuat nilai-nilai bersama serta keyakinan masyarakat. Ritual juga dapat membantu menciptakan rasa yang kuat dari identitas sebuah kelompok. Orangorang dalam sebuah masyarakat telah menggunakan ritual untuk menciptakan ikatan sosial dan bahkan untuk memelihara hubungan interpersonal.

Salah satu ritual yang terjadi adalah ritual dalam agama Buddha. Ritual Buddhis adalah seluruh kegiatan yang dilakukan dan berhubungan dengan peningkatan keyakinan terhadap agama Buddha. Ritual Buddhis meliputi kegiatan puja bhakti atau kebaktian. Alasan umat Buddha melaksanakan ritual adalah untuk meningkatkan keyakinan terhadap Tiratana dan teringat pada ajaran Buddha. Inti ajaran Buddha antara lain, menghindari perbuatan buruk, melakukan perbuatan baik, dan mensucikan hati dan pikiran.

Salah satu contoh ritual di masyarakat Desa Gembongan adalah pelaksanaan selamatan sebelum kegiatan panen padi dimulai. Selamatan atau selametan adalah tradisi ritual yang dilaksanakan oleh masyarakat Jawa. Selamatan ini merupakan suatu bentuk acara syukuran dengan mengundang beberapa kerabat atau tetangga. 
Menurut Cilfford (1973: 3) slamatan adalah versi Jawa yang merupakan upacara keagamaan paling umum di dunia, pesta komunal (pesta rakyat). Acara selamatan sendiri dimulai dengan membaca doa bersama, dengan duduk bersila diatas tikar, melingkari sesajian yang akan digunakan untuk kegiatan selamatan.

Selamatan merupakan adat yang tidak bisa dilepaskan dengan akar sejarah kepercayaan-kepercayaan yang pernah dianut masyarakat Jawa. Kegiatan selamatan bertujuan untuk memperoleh keselamatan. Manusia pada mulanya merasa tidak berdaya, kemudian memohon perlindungan kepada sesuatu yang memiliki kekuatan lebih, yang dapat disebut dengan roh-roh dan kekuatan yang terdapat pada benda-benda tertentu. Kegiatan seperti itu kemudian dapat dikenal sebagai "selamatan" (Tawab, 2014:2). Hakikat dari selamatan adalah sebagai wujud syukur, untuk mendapatkan berkah, selamat dan terhindar dari berbagai cobaan yang berat, mendoakan orang yang meninggal, agar kehidupan bermasyarakat menjadi aman dan tenteram. Unsur naturalisme dalam kegiatan selamatan yaitu menggunakan alam sebagai wujud syukur, misalnya menggunakan sesajen untuk pelaksanaan kegiatan methik pari (panen) yang dilakukan sekelompok orang atau individu.

Methik pari atau yang biasa dikenal dengan sebutan panen merupakan kegiatan dalam budidaya di bidang pertanian yang dilakukan pada akhir untuk menikmati hasil kerja keras selama merawat dan menjaga sesuatu yang dibudidayakan. Kegiatan panen dalam bidang pertanian meliputi pemotongan malai, pengumpulan malai, perontokan dan pembersihan gabah, pengeringan, penyimpanan, penggilingan, dan pengemasan yang sudah dalam bentuk beras. Sebelum pelaksanaan methik pari, masyarakat Desa Gembongan melaksanakan ritual selamatan sebagai tanda syukur kepada Tuhan Yang Maha Esa karena dapat merasakan hasil dari usaha bercocok tanam yang telah masyarakat lakukan. Setelah masyarakat melakukan ritual selamatan kemudian masyarakat membawa ambengan atau sesajian untuk di bawa ke sawah dengan harapan panen melimpah dan lancar. Kemudian ambengan atau sesajian tersebut di bawa di pojokan sawah dengan garis lurus tidak boleh melawan arah karena dalam tradisi tersebut merupakan pantangan yang tidak boleh dilanggar. Dalam tradisi ini ambengan atau sesajian yang sudah diletakan di pojokan sawah dibacakan doa dan ambengan tersebut di gagak'i (mengambil ambengan atau sesajian tersebut).

Upacara selamatan ini sudah dilakukan sejak zaman dahulu. Ritual selamatan ini selalu dilakukan masyarakat Desa Gembongan sebelum memanen padi. Ritual ini diadakan setiap tahun sekali sejak zaman nenek moyang dan dilakukan turun temurun 
sampai sekarang. Dalam ritual selamatan methik pari terdapat berbagai sarana prasarana yang digunakan sebagai penunjang dalam mencapi tujuan yang sudah ditetapkan. Penunjang untuk melakukan ritual methik pari antara lain: cok bakal, sega takir, merang mayan dan kemenyan. Ritual ini tentu memilik bentuk dan makana tersendiri serta mempunyai ciri khas tersendiri dibandingkan dengan tempat lain yang melakukan ritual methik pari. Meskipun ritual ini dilakukan sejak zaman nenek moyang, tetapi hanya orang-orang tertentu khususnya generasi tua yang benar-benar memahami makna dari ritual methik pari tersebut. Hal ini diperkuat oleh salah satu pernyataan dari pemuda berinisial X di Desa Gembongan yang belum memahami makna dari ritual methik pari dalam pandangan Agama Buddha. Pernyataan dari $\mathrm{X}$ menyatakan bahwa makna ritual methik pari sebagai ungkapan terimakasih kepada Tuhan Yang Maha Esa. Makna dari ritual methik pari sebenarnya tidak hanya sebagi ungkapan terimakasih kepada Tuhan Yang Maha Esa tetapi ada makna lain yang terdapat dalam ritual methik pari.

Kenyataan lain yang terjadi berdasarkan wawancara yang dilakukan peneliti pada tanggal, 1 Juni 2018 dengan salah satu umat beragama Buddha yang merupakan petani padi dengan inisial $S$ menyatakan bahwa, ritual selamatan methik pari yang dilakukannya hanya mengikuti tradisi methik pari secara turun-temurun. Berdasarkan uraian tersebut dapat disimpulkan bahwa tidak semua masyarakat di Desa Gembongan memahami makna yang terkandung dalam ritual methik pari melainkan hanya orang-orang tertentu yang mengetahuinya.

Berdasarkan permasalahan yang terjadi pada masyarakat Desa Gembongan mengenai ritual selamatan methik pari maka peneliti tertarik untuk melakukan penelitian dengan judul "Makna Simbolik Ritual Selamatan Methik pari Dalam Pandangan Agama Buddha Di Desa Gembongan, Kecamatan Ponggok, Kabupaten Blitar". Berdasarkan latar belakang masalah di atas maka rumusan masalah dalam penelitian ini adalah: 1) Bagaimana sejarah selamatan ritual methik pari yang ada di Desa Gembongan Kecamatan Ponggok, Kabupaten Blitar ?, 2) Apa makna simbolik ritual selamatan methik pari di Desa Gembongan, Kecamatan Ponggok, Kabupaten Blitar ?, 3) Bagaimana makna simbolik ritual selamatan methik pari dalam pandangan Agama Buddha di Desa Gembongan, Kecamatan Ponggok, Kabupaten Blitar?

\section{METODE PENELITIAN}

Metode yang digunakan dalam penelitian adalah metode penelitian kualitatif dengan pendekatan studi kasus. Alasan peneliti memilih studi kasus karena ada 
keunikan tersendiri dari upacara ritual selamatan methik pari di Desa Gembongan dengan ritual selamatan methik pari yang berada di daerah lain.. Metode penelitian kualitatif adalah metode penelitian yang digunakan untuk meneliti pada kondisi obyek yang alamiah, (sebagai lawannya adalah eksperimen) dimana peneliti adalah sebagai instrument kunci. Teknik pengumpulan data di lakukan secara trianggulasi (gabungan), analisis data bersifat induktif dan hasil dari penelitian kualitatif lebih menekankan makna dari pada generalisasi (Sugiyono, 2013: 1).

Penulis memilih menggunakan metode penelitian kualitatif karena lebih efektif apabila berada dilapangan. Penggunaan metode kualitatif ini memudahkan peneliti dalam melakukan wawancara dan pengamatan. Melalui wawancara dan pengamatan akan memudahkan peneliti untuk mengumpulkan data. Kemudian data hasil dari wawancara dan pengamatan akan dilanjutkan dengan analisis data dan akan lebih cepat menemukan hal-hal yang baru.

\section{HASIL PENELITIAN DAN PEMBAHASAN}

\section{Sejarah ritual selamatan methik pari}

Tradisi ritual selamatan methik pari yang dilakukan oleh masyarakat Desa Gembongan telah ada dari zaman nenek moyang. Masyarakat Desa Gembongan yang mayoritas bekerja sebagai petani telah lama menjalankan tradisi ini. Hal ini seperti yang disampaikan oleh Bapak Karni yang menyatakan bahwa sejarah ritual selamatan methik pari sudah dilakukan oleh masyarakat Desa Gembongan, Kecamatan Ponggok, Kabupaten Blitar sudah dilakukan sejak zaman nenek moyang. Kemudian masyarakat desa hanya menuruskan tradisi atau budaya yeng sudah dilakukan sejak zaman dahulu.

Penjelasan dari bapak Karni tentang sejarah selamatan methik pari yang ada di Desa Gembongan didukung oleh pernyataan bapak Sunyoto yang menyatakan bahwa sejarah awal mula ritual selamatan methik pari hampir sama dengan yang dijelaskan dari wawancara dengan bapak karni sebelumnya, bahwasanya sejarah ritual selamatan methik pari telah ada dari zaman nenek moyang dan secara turun temurun diwariskan kepada generasi sekarang. Dengan diwariskannya ritual tersebut masyarakat turut andil dalam melestarikan budaya yang telah diwariskasn oleh nenek moyang. Ritual selamatan methik pari sering dikaitkan dengan ritual penghormatan kepada Mbok Sri Sedono dan Joko Sedono sebagai pemberi rezeki dalam mitos Jawa. Oleh karena itu setiap menjelang panen tiba masyarakat akan mengadakan rial selamatan methik pari dengan memberikan sesajian berupa cok bakal, nasi takir, dan dupa. Jadi dapat disimpulkan bahwa sejarah awal mula dari ritual selamatan methik pari 
sudah dimulai sejak manusia ada di tanah Jawa. Kemudian ritual selamatan methik pari ini diwariskan kepada generasi yang penerus dan ritual selamatan methik pari masih dilakukan oleh masyarakat sampai sekarang.

Dengan disimpulkannya dari pernyataan di atas adalah ritual selamatan methik pari yang dilakukan oleh masyarakat Desa Gembongan, Kecamatan Ponggok, Kabupaten Blitar hanya meneruskan tradisi atau budaya yang sudah dilakukan sejak zaman dahulu secara turun-temurun. Hal ini sependapat dengan Situmorang, (2004: 175) yang menjelaskan bahwa "ritual adalah suatu hal yang berhubungan terhadap keyakinan dan kepercayaan spiritual dengan tujuan tertentu". Pengertian tersebut mengandung arti bahwa ritual merupakan aktivitas yang berhubungan dengan keyakinan dan spiritual, keyakinan yang terbentuk inilah yang kemudian menjadi tradisi masyarakat dan dilakukan secara turun temurun selayaknya ritual selamatan methik pari.

\section{Makna Simbolik Ritual Selamatan Methik pari}

Adat-istiadat atau tradisi adalah merupakan peninggalan warisan dari sebuah budaya yang telah ada dalam suatu daerah. Seperti halnya masyarakat Desa Gembongan yang sampai sekarang masih melakukan ritual selamatan methik pari. Ritual selamatan methik pari merupakan adat yang dilakukan oleh petani setiap akan melakukan panen padi. Ritual selamatan methik pari ini dilakukan oleh perorangan atau seacara individu untuk memanjatkan rasa syukur dari apa yang telah diberikan oleh Tuhan dan para leluhurnya. Sebagai tanda terimakasih masyarakat desa melakukan ritual selamatan methik pari untuk mengirimkan doa untuk para leluhur. Karena masyarakat desa masih mempercayaai adanya Mbok Sri Sedono dan Joko Sedono yang menjaga tanaman padi agar tidak terkena hama padi dan mendapatkan hasil panen yang melimpah.

Masyarakat Desa Gembongan Kecamatan Ponggok Kabupaten Blitar, secara turuntemurun mengadakan ritual selamatan methik pari. Ritual selamatan methik pari perlu mempersiapkan cok bakal, nasi takir, dan dupa atau kemenyan. Dari sajian ini masingmasing mempunyai makna tersendiri yang merupakan representasu dari filosofi hidup masyarakat setempat. Berikut adalah makna dari sajian dari ritual selamatan methik pari :

a. Cok Bakal

Artinya menurut keyakinan cok bakal berasal dari kata "cok/pecok" yang artinya cikal/asal dan "bakal” yang berarti awalan, jadi kalau dimaknakan artinya manusia tidak boleh lupa dengan asal usulnya atau orang tuanya. Selain itu cok bakal merupakan simbologi permulaan dalam kehidupan yang berawal dari ketiadaan menjadi ada, serta merupakan penghubung antara Tuhan dengan 
umatnya. Dalam menjalani kegiatan kemasyarakatannya, masyarakat Jawa menggunakan cok bakal sebagai media awal dalam melaksanakan suatu kegiatan serta sebagai simbolik syukur kepada Tuhan agar kegitan yang dilaksanakan lancar tanpa halangan.

b. Nasi Takir

Artinya Takir berasal dari kata tatake piker. Takir mempunyai empat sisi yang menggambarkan persaudaraan yang terbentuk dari empat unsur alam yaitu air, api, tanah dan udara yaitu semua yang ada pada dunia. 4 (Empat) unsur alam tersebut yang dapat dijabarkan seperti di bawah ini.

1) Unsur air merupakan benda cair yang terdapat dalam alam semesta, sedangkan air dalam manusia berada pada zat cair seperti darah, keringat, air liur dan sebagainya atau segala yang berbentuk cair dalam tubuh.

2) Unsur api merupakan segala bentuk panas yang terdapat dalam alam besar dan alam kecil. Jika dilihat lebih dekat api pada manusia terdapat panas pada badan.

3) Unsur tanah merupakan zat atau unsur padat yang ada pada alam semesta seperti Tanah. Sedangkan kalau pada manusia tanah ada pada bagaian kulit atau daging manusia atau segala zat padat pada manusia.

4) Unsur udara yang terdapat dalam alam semesta seperti angin, udara dan lainnya. Sedangkann pada manusia terdapat pada nafas manusia atau segala bentuk angin pada manusia.

c. Dupa

Artinya, dupa atau kemenyan merupakan penggambaran diri seseorang yang telah berbuat baik dan nama seseorang baik akan dikenal banyak orang karena kebaikan yang dimiliki dimanapun ia berada. Sarana atau sesajian yang digunakan dalam upacara selamatan methik pari di atas memiliki arti atau maksud. Sarana atau sesajian yang digunakan merupakan simbol dari sebuah makna yang disampaikan melalui bentuk barang. Hal ini diperkuat dalam buku "The Harper Collins Of Religion" yang menjelaskan bahwa penggunaan simbol sebagai alat komunikasi. Dipergunakannya simbol dapat mewakili dalam suatu peristiwa pada sesuatu yang mewakili arti atau makna, misalanya, patung, arsitektur, warna, doa, mitos, ritual dan hal-hal lain yang mempunyai arti pada peristiwa penting dalam suatu masyarakat setempat (Jhonathan, 1995:1038). 


\section{Makna Simbolik Ritual Selamatan} Methik pari Dalam Pandangan Agama

\section{Buddha}

Masyarakat Desa Gembongan pada dasarnya memiliki dua macam cara ritual yang berbeda yaitu menggunakan cara ritual secara umum dan menggunakan ritual secara keagamaan. Ritual secara keagamaan disini adalah ritual secara pandangan Agama Buddha. Agama Buddha memiliki upacara/ritual seperti kebaktian rutin, tujuh bulanan kandungan, menjelang kelahiran, ulang tahun, penempatan rumah baru, pattidana, dan pemberkahan benih. Ritual keagamaan ini dilakukan oleh umat beragama Buddha dan menggunakan simbol-simbol yang ada dalam Agama Buddha. Acara ritual tersebut bisa dilakukan di vihara maupun di rumah umat sesuai yang diinginkan oleh yang punya hajat. Untuk melakukan ritual Agama Buddha membutuhkan simbol-simbol antara lain yaitu: lilin, dupa, bunga, air, dan rupang. Jadi ini membuktikan bahwa ritual dalam Agama Buddha dan ritual selamatan methik pari memiliki persamaan dari simbol dan pemaknaan.

Mengenai persamaan makna dari makna simbolik ritual selamatan methik pari bila dilihat dari pandangan Agama Buddha yaitu:

\section{a. Cok Bakal}

Cok Bakal dalam ritual selamatan methik pari memiliki makna bahwa setiap orang atau manusia tidak boleh lupa akan asal-usulnya. Khususnya kepada orang tua dan para leluhurnya karena di dalam cok bakal terdapat bibit tanaman yang berhubungan dengan bumbu dapur yang dapat digunakan sebagai obat. Keterkaitan cok bakal dalam pandangan agama Buddha adalah bahwa cok bakal yang dipersembahkan dalam ritual selamatan methik pari bila dikaitkan dengan pandangan agama Buddha sama dengan kita telah melakukan benik-benih perbuatan baik dan jasanya kita limpahkan kepada para leluhur atau semua mahkluk khususnya kepada orang tua kita yang disebut dengan istilah patidana.

Patidana dalam agama Buddha tertuang dalam Sigalaka Sutta. Buddha membabarkan kotbah ini berawal dari pemuda yang bernama Sigālaka putra seorang perumah tangga yang menyembah arah untuk menghormati orang tuanya yang sudah meninggal. Sigālaka melakukan itu hanya untuk mengindahkan apa yang dikatakan orang tuanya sebelum meninggal. Buddha kemudian memberikan solusi yang baik dan benar bagaimana cara melakukan penghormatan yang benar kepada orang tua sebelum dan setelah meninggal yang sesuai dengan ajaran-Nya.

Ada lima cara bagi seorang putra menghormati orang tua sebagai arah timur yaitu: 
"(1) Setelah disokong, aku harus menyokong mereka; (2) Melakukan tugas-tugas mereka; (3) Menjaga tradisis keluarga; (4) Menjaga nama baik keluarga; dan (5) Setelah mereka meninggal dunia, aku akan membagkan persembahan mewakili mereka atau melakukan patidana (pelimpahan jasa) kepada mereka." ( Walshe, 2009: 483).

Jadi dapat disimpulkan mengenai penjelasan di atas adalah kita sebagai anak harus berbakti kepada orang tua, menjaga tradisi keluarga, menjaga nama baik orang tua dan setelah orang tua meninggalpun kita harus tetap berbakti kepeda orang tua dengan memberikan persembahan atau pelimpahan jasa.

\section{b. Nasi Takir}

Nasi takir memilik makna persaudaraan yang terdiri dari empat unsur alam yang meliputi air, api, tanah dan udara. Bila dihubungan dalam agama Buddha maka akan berhubungan dengan Mahabuta 4 (empat) yaitu 4 unsur terbentuknya jasmani (Rupakhanda) yang termuat dalam Samyuta Nikaya 22: 48-79). Ke-empat unsur itu adalah:

1) Unsur pada yang secara harfiah berarti "tanah" (Pathavi Dhatu) yang sebenarnya memberikan sifat atau kemampuan menepati ruang dan mempertahankan posisi serta memberikan sifat kaku pada setiap materi.

2) Unsur cair (Apo Dhatu) yang sebenarnya berupa gaya rekat atau tarik menarik antara materi.

3) Unsur panas atau energy (Tejo Dhatu) yang sebenarnya memiliki sifat mahabhuta yang lain tetapi dalam demensi yang lebih kecil.

4) Unsur gerak atau getaran (vayo Dhatu) yang bila dalam kesimbangan dengan unsur cair akan menampakan eksistensi padat materi yang bersangkutan dari interaksi ke-empat unsur halus ini terbentuklah tuuh kita yang terdiridari dagimg, darah, tulang, dan sebagainya.

Selain itu, nasi takir merupakan bentuk nyata dari kepedulian masyarakat di tengahtengah kesederhanaan bila dihubungkan dengan agama Buddha maka tradisi nasi takir juga sebagai sarana untuk berdana. Karena dengan hanya satu bungkus nasi takir orang bisa memberikan dana makanan kepada orang tidak mampu dan membuktikan bahwa dengan hidup yang serba kekurangan masyarakat masih memiliki rasa berbagi yang kuat kepada sesama dengan memberikan nasi takir kepada orang lain.

Kesimpulan yang peneliti simpulan dari makna simbolik nasi takir dalam agama Buddha yaitu ada makna mahabhuta 4 (4 
unsur terbentuknya jasmani dan ada makana dana).

c. Dupa

Dupa dalam ritual selamatan methik pari memiliki makna cinta kasih kepada semua mahkluk. Sedangkan dalam pandangan agama Buddha, dimana setiap hari umat Buddha menyalakan dupa ketika melakukan Pujabakti. Dupa memiliki makna keharuman. Dupa dalam ritual selamatan methik pari dengan agama Buddha berbeda, tetapi pada dasarnya sama yaitu, dimana pun manusia itu berda tetapi orang tersebut melakukan perbuatan baik, menebarkan cinta kasih dan kesucian kepada orang seperti harumnya dupa yang menyebarkan keharuman keseluruh alam dimana angin membawanya. Seperti kutipan dalam Dhammapada IV : 55 diwah ini :

Candanaì tagaram vā'pi uppalaim atha vassikī etasam gandhajātānam sīlagandho anuttaro. Yang berarti harumnya bunga dapat mengalahkan harumnya kayu cendana, bunga tagara, bungan teratai atau bunga melati. (Widya, 2011: 22).

Simbol-simbol yang digunakan dalam ritual selamatan methik pari di Desa Gembongan, Kecamatan Ponggok, Kabupaten Blitar merupakan perwakilan dari sebuah maksud atau tujuan tertentu. Hal ini sependapat dengan Mukti (2003: 63) dalam buku Wacana Buddha Dhamma dijelaskan bahwa simbol memiliki maksud dan tujuan tertentu. Simbol dalam agama dipandang sebagai ungkapan indrawi atas pemikiran dan realitas yang trensenden. Simbol tidak menujukan langsung apa yang digambarkan seperti benda daripada itu simbol mengandung arti mempengaruhi perasaan, yang berhubungan dengan konsep keyakinan. Simbol pada dasarnya adalah sarana yang mengandung suatu pertanyaan khusus dimana makna tersebut berhubungan dengan karakteristik visual dari tanda yang digunakan.

Simbol erat berhubungan dengan suatu ritual dalam sebuah tradisi. Perpaduan antara budaya Jawa dengan tradisi yang ada dalam agama Buddha akan menjadi keunikan tersendiri dibandingkang dengan agama-agama yang lain. Hal ini akan menjadi bervariatif ketika umat Buddha dalam menjalankan sebuah ritual keagamaannya. Untuk mengetahui unsur budaya lokal disetiap ritual keagamaan yang dilakukan oleh umat Buddha. Budaya lokal yang sering dilakukan dalam upacara keagamaan seperti dalam perayaan waisak, asadha, khatina, dan magha puja biasanya diadakan genduri. Ini membuktikan bahwa budaya lokal Jawa dengan agama Buddha saling mengikuti. Seperti yang dijelaskan oleh Buddha dalam Kalama Sutta sesungguhnya seseorang hendaknya tidak begitu saja 
menolak atau menerima suatu tradisi tanpa mempertimbangkan dahulu apakah semacam itu bermanfaat atau memiliki makna baginya (Bodhi, 2015: 338) .

Ritual methik pari merupakan suatu tradisi yang sudah dilaksanakan secara turuntemurun. Ritual tersebut memiliki makna tersendiri bagi petani khususnya petani Buddhis. Ritual yang dilakukan merupakan persembahan sekaligus wujud bakti dan penghormatan terhadap leluhur. Berdasarkan wawancara yang dilakukan dengan Bapak Minto pada tanggal 052018 menjelaskan bahwa:

"Ya, berdasarkan doa-doa yang dibacakan dan harapan dari para petani, selalu menjaga dan berbakti kepada para leluhur"

Wawancara tersebut mengandung arti bahwa ritual selamatan methik pari yang dilakukan masyarakat Buddhis merupakan bentuk pattidana atau persembahan dan bakti (penghormatan) yang ditujukan kepada leluhur dengan harapan untuk menghormati para leluhur.

Dalam Tirokudda Sutta, menjelaskan dengan bahasa Pali yaitu "Yatha varivaha pura paripurenti sagaram evameva ito dinnam petanam upakappati" yang artinya sebagaimana sungai yang meluap airnya akan mengalir memenuhi lautan; demikianlah persembahan yang disampaikan oleh sanak keluarga dari alam manusia akan menuju ke para leluhur (Dhammadhiro, 2005: 190), dengan demikian buah dari kebajikan dilakukan, akan melimpah kepada sanak keluarga yang telah meninggal bila masih di alam peta.

Tujuan daripada pattidana sendiri adalah untuk membantu para leluhur yang terlahir di alam menderita serta perwujudan bakti pada sanak keluarga atau leluhur kita. Di dalam Dakkinavibhanga Sutta Sang Buddha menjelaskan bahwa tempat atau ladang keluarga untuk dapat berbuat kebajikan kepada para leluhur, untuk mengodisikan leluhurnya telah terbantu yaitu dengan berdana dengan Bhikkhu Sangha (Ñanamoli 2013: 1795). Seseorang yang sering melakukan ritual tersebut akan mendapatkan berbagai manfaat diantaranya adalah (1) keyakinan terhadapat Buddha, Dhamma, Sangha, yang akan mengingatkan kita kepada ajaran Sang Buddha, (2) seseorang akan mengerti makna yang terdapat pada ritual dan akan mengikis kemelekatan pada dirinya.

\section{KESIMPULAN}

Berdasarkan rumusan masalah dalam penelitian ini peneliti dapat menyimpulkan bahwa "Makna simbolik ritual selamatan methik pari dalam pangangan agama Buddha yaitu:

1. Sejarah ritual selamatan methik pari dilakukan sejak zaman nenek moyang. 
Masyarakat mempercayai adanya Mbok Sri Sedono dan Joko Sedono yang menjaga tanaman padi agar tidak terkena hama. Masyarakat memberikan sesajian untuk leluhur. Sesajian itu berupa cok bakal, nasi takir, dan dupa.

2. Makna simbolik tradisi ritual selamatan methik padi adalah untuk mengingat para leluhur yang menjaga keseimbangan hidup selaras manusia, alam dan leluhur yaitu memberikan penghormatan kepada leluhur dan sebagai ungkapan terima kasih kepada para leluhur dan Tuhan Yang Maha Esa serta atas keberhasilan dan keselamatan.

3. Makna simbolik ritual selamatan methik pari dalam pandangan Agama Buddha adalah sebagai bentuk penghormatan kepada para leluhur yang dapat diwujudkan dalam bentuk; (1) Pattidana yang digambarkan dalam sesajian cok bakal; (2) Empat Mahabuta yang terdiri dari Pathavi Dhatu, Apo Dhatu, Tejo Dhatu, Vayo Dhatu dan dana yang digambarkan dalam sesajian nasi takir; (3) Keharuman kebajikan yang digambarakan dalam bentuk persembahan dupa.

\section{DAFTAR PUSTAKA}

Bhikkhu Bodhi. (2015). The Numerical Discourses of the Buddha A Translation of the Añguttara Nikāya. Jakarta Barat: DhammaCitta Press
Bhikkhu Ñāṇamoli. (2013). The Middle

Length Discourses of the Buddha

A Translation of the Majjhima Nikāya. Jakarta Barat: DhammaCitta Press

Dhammadhiro. (2005). Paritta Suci. Jakarta: Yayasan Sangha Theravada Indonesia.

Koentjaningrat. (1984). Kebudayaan Jawa. Jakarta: Gramedia -(1990). Sejarah Teori Antropologi. Jilid 1. Jakarta : UI Press.

Mingun. (2009). Riwayat Agung Para Buddha. Jakarta: Ehipassiko Foundation.

Mukti \& Wijaya Krisnanda. (2003). Wacana Buddha-Dharma. Jakarta: Yayasan Dharma Pembangunan \& Sangha Agung Indonesia.

Sugiyono. (2013). Memahami Penelitian Kualitatif. Bandung : Alfabeta

Sujarwo. (1998). Manusia dan Fenomena Budaya. Yogyakarta: Pustaka Belajar.

Widya Surya. (2011). Dhammapada. Jakarta Utara: Yayasan Abdi Dhamma Indonesia.

Tawab. (2014). Skirpsi. Pemikiran K.H. Muhammad Sholikhim Tentang Tradisi Selamtan. Universitas Islam Negeri Sunan Kalijaga Yogyakareta, Fakultas Filsafat Agama. 